\title{
Serological Relationships in the Leptodactylus pachypus Species Group (Amphibia, Salientia)
}

José M. Cei and Raquel Cohen

\begin{abstract}
Precipitin tests indicate that Leptodactylus ocellatus and $L$. chaquensis are more closely related than either is to $L$. pentadactylus. However, the serological differences between $L$. ocellatus and $L$. chaquensis support a separate specific ranking for these forms. Populational variations of the specific antigens occur in all 3 species.
\end{abstract}

\section{INTRODUCTION}

$\mathrm{T}^{\mathrm{n}}$ HE existence of physiological and sibling species of amphibians has been discovered during recent years. In the case of Leptodactylus, a very puzaling problem in the $L$. ocellatus complex has been pointed out by one of us (Cei 1948, 1949, 1950). Among the neotropical forms of the $L$. pachypus stock (or subgenus), we can consider at first 2 groups of frogs: the ocellatus-bolizianus group and the pentadactylus group, both widely distributed in the cis-Andine continental belt. In addition to many distinctive morphological features, differences in some physiological or metabolic characters of these groups have recently been found, e.g., the presence in the skin of different, probably opposite, enzymatic systems for bioamine synthesis leading to phenylalkylamines (Leptodactyline) in the ocellatus-bolivianus group, and to indolalkylamines (5-H-triptamine and derivatives) in the pentadactylus group (Erspamer and Cei 1963). But in the ocellatus-bolivianus group, the widespread ocellatus complex, formerly a Linnean taxon (Leptodactylus ocellatus = Rana ocellata Linné), includes 2 closely related, partly sympatric species which can be distinguished by many physiological characters but by few morphological ones. There are, for example, striking differences in the male scx cycle and sex character regulation (Cei 1948, 1949, 1950, 1962; Cohen 1962), a remarkable difference in the electrophoretic properties of the hemoglobins (Bertini and Rathe 1962), considerable chromatographic difference in the Leptodactyline content of the skin (Cei and Erspamer 1963) and a strikingly different populational distribution of the seroprotein electrophoretic patterns (Cei and Bertini 1961, Gallopin 1962). These sibling species, reptodactylus chaquensis Cei and $L$. ocellatus (Linné), are found in well-defined areas, overlapping in more or less extensive zones from northeastern Brazil to the Parana River
(Santa Fe, Argentina). It appeared worthwhile applying to these sibling species of the ocellatus complex the criterion of serological affinity, as indicated by precipitin tests. In the present paper, we report on such tests of serum samples of Leptodactylus ocellatus and L. chaquensis populations in comparison with those of the more distantly related $L$. pentadactylus.

It is a pleasure to acknowledge the courtesy of Dr. Alan Boyden of Rutgers University. We are greatly indebted to him for reviewing this article.

\section{Material and Methods}

Hemolysis-free pooled sera (antigens) obtained by cardiac puncture from recently captured adult specimens were used. All stored sera were preserved with merthiolate $(1: 10,000)$ as recommended by Boyden and De Falco (1943) and Boyden and Gemeroy (1950). Because of the small quantity of antigens available, the rabbits were injected by a single series of 3 injections, spaced 2 weeks and 1 week apart, successively. In all cases, the initial and each subsequent injection was $2 \mathrm{mg}$ of protein per $\mathrm{kg}$ of rabbit body weight, but in every case reinforced by the addition of $1 \mathrm{ml}$ of Twen 80 to each $1 \mathrm{ml}$ of antigen, as coadjuvant. Eight days after the last injection, a trial bleeding was taken, and on the following day the animals were bled by cardiac puncturc and the blood allowed to clot in the refrigerator. The decanted sera were centrifuged, then Seitz filtered, and the antisera bottled under sterile conditions and stored at $5 \mathrm{C}$. The precipitin tests followed the techniques of Boyden (1942) and co-workers. A Libby Photroner (AMINCO Universal Model) was used. This unit was specially modified by us to work with direct current $(6 \mathrm{~V})$. Only thus could we obtain a well-stabilized line adequate to the Photroner's galvanometric sensitivity. 
Tarle 1. Precirimin Tests of Leptodactylus Antisera.

\begin{tabular}{|c|c|c|c|c|c|}
\hline $\begin{array}{c}\text { Anti- } \\
\text { serum }\end{array}$ & Kind & $\begin{array}{c}\text { Homol- } \\
\text { ogous } \\
\text { Area }\end{array}$ & $\begin{array}{l}\text { Heterol- } \\
\text { ogous } \\
\text { Area }\end{array}$ & Kind & $\begin{array}{c}\text { Percentage } \\
\text { Heterol. Area } \\
\text { Homol. Area }\end{array}$ \\
\hline CB-11 & L. ocellatus-San Luis & 253 & 253 & $\begin{array}{l}\text { L. ocellatus } \\
\text { Mendoza-0197 }\end{array}$ & 100.00 \\
\hline$"$ & $"$ & 253 & 168 & $\begin{array}{l}\text { L. chaquensis } \\
\text { Tucuman-0.137 }\end{array}$ & 66.4 \\
\hline$"$ & $"$ & 253 & 132 & $\begin{array}{l}\text { L. chaquensis } \\
\text { Resistencia-0179 }\end{array}$ & 52.1 \\
\hline$"$ & $"$ & 253 & 149 & $\begin{array}{l}\text { L. pentadactylus } \\
\text { Misiones-0164 }\end{array}$ & 58.8 \\
\hline CB-8 & L. chaquensis-Tucuman & 416 & 405 & $\begin{array}{l}\text { L. chaquensis } \\
\text { Resistencia-0179 }\end{array}$ & 97.3 \\
\hline$"$ & $"$ & 416 & 330 & $\begin{array}{l}\text { L. ocellatus } \\
\text { Mendoza-0197 }\end{array}$ & 79.3 \\
\hline$"$ & $"$ & 416 & 298 & $\begin{array}{l}\text { L. ocellatus } \\
\text { San Luis-0136 }\end{array}$ & 71.6 \\
\hline$"$ & $"$ & 416 & 346 & $\begin{array}{l}\text { L. ocellatus } \\
\text { Bahia Blanca-0174 }\end{array}$ & 83.1 \\
\hline$"$ & $"$ & 416 & 236 & $\begin{array}{l}\text { L. pentadactylus } \\
\text { Misiones-0-164 }\end{array}$ & 56.7 \\
\hline CB-10 & L. pentadactylus-Misiones & 333 & 160 & $\begin{array}{l}\text { L. ocellatus } \\
\text { San Luis- } 0136\end{array}$ & 48.0 \\
\hline$"$ & $"$ & 333 & 208 & $\begin{array}{l}\text { L. ocellatus } \\
\text { Mendoza-0197 }\end{array}$ & 62.4 \\
\hline$"$ & $"$ & 333 & 168 & $\begin{array}{l}\text { L. ocellatus } \\
\text { Bahia Blanca-0174 }\end{array}$ & 50.4 \\
\hline$"$ & $"$ & 333 & 141 & $\begin{array}{l}\text { L. chaquensis } \\
\text { Tucuman-0137 }\end{array}$ & 42.3 \\
\hline " & " & 333 & 203 & $\begin{array}{l}\text { L. chaquensis } \\
\text { Resistencia-0179 }\end{array}$ & 60.9 \\
\hline
\end{tabular}

Serum samples of the following species and populations were used, their numbers referring to our register of antigens:

Leptodactylus ocellatus:-SAN LuIS (Sierras: 1,000 mosl) Argentina. Mendoza (near the town: 800 mosl) Argentina. BAHIA BLANCA (Buenos Aires Province: mosl) Argentina.

L. chaquensis:-Tucuman (near the town: 450 mosl) Argentina. Resistencia (Chaco: 60 mosl) Argentina.

L. pentadactylus:-OBERÁ (Misiones: 700 mosl) Argentina.

Antisera are conventionally numbered in agreement with the successive operational series of our laboratory. As is customary, we graphed the amounts of turbidity in the reactions between the antisera and the antigens of the various dilutions. The graphed area of a homologous reaction was considered the reference standard for all tests with a particular antiserum, and was rated at $100 \%$. Each heterologous reaction was then compared to the appropriate homologous one and a percentage relationship determined in accordance with their relative areas of precipitation.

Because of the small quantities of our batrachian sera available, all the progressive antigen dilutions were begun at $1: 5$ (Evans Buffer) even though the zone of excess antigen often lies to the left of the beginning of the curves of turbidities plotted in our graphs. The zone of excess antigen could be reached with these antisera only by a $1: 2.5$ or $1: 1$ dilution. At any rate, the lack of the excess antigen zone at $1: 5$ dilutions does not substantially change, in the present case, the comparative serological significance of the heterologous/homologous area ratios.

\section{REsults}

Intrageneric and specific variations of serum proteins of Leptodactylus and their relationships can be easily appreciated and compared by precipitin tests (Table 1). All 


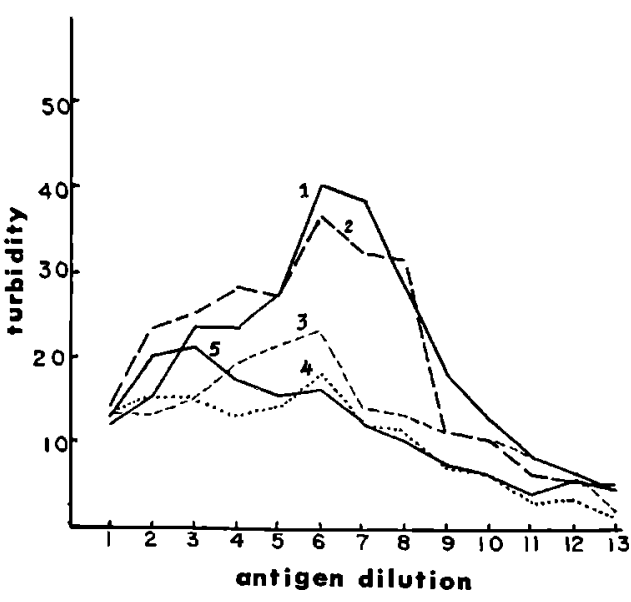

Fig. 1. Results of tests of the antiserum of the Leptodactylus ocellatus-San Luis population with its homologous (curve 1) and heterologous antigens (curves $2-5$ ). The amounts of turbidity or precipitate are shown on the ordinate for each of the antigen dilutions indicated along the abscissa. Dilution 1 represents a $1: 5$ dilution of the serum in buffered saline, and each succeeding dilution is double the preceding one. Forms represented in the curves: $2, L$. ocellatus, Mendoza; 3, L. chaquensis, Tucuman; 4, L. chaquensis, Resistencia; $5, L$. pentadactylus, Misiones.

the antisera here employed show reactions between Leptodactylus ocellatus, chaquensis, and pentadactylus, the progressive weakness of the total turbidity agreeing with the suspected relative systematic and biological distance between these frogs (Figs. 1, 2, 3).

The serological distances which separate $L$. pentadactylus and the sibling species $L$. ocellatus and chaquensis are wider than serological distances between these closely related forms. However, the highest reciprocal relationship values of $66.4 \%$ and $83.1 \%$ found between ocellatus of any tested population and chaquensis from Tucuman show that these sibling species are really distinct.

Summarizing the results shown by Table 1 , the average of percentages of heterologous/ homologous areas between $L$. ocellatus populations and $L$. chaquensis from Tucuman is $75.1 \%$, with a range of 66.4 to $83.1 \%$.

Average of percentages between $L$. pentadactylus and $I$. ocellatus populations is $54.9 \%$, range, 48.0 to $62.4 \%$. The average value between $L$. pentadactylus and $L$. chaquensis is $53.3 \%$, range, 42.3 to $60.9 \%$. The similarity in these values is striking. The percentage value between $L$. ocellatus from San Luis and

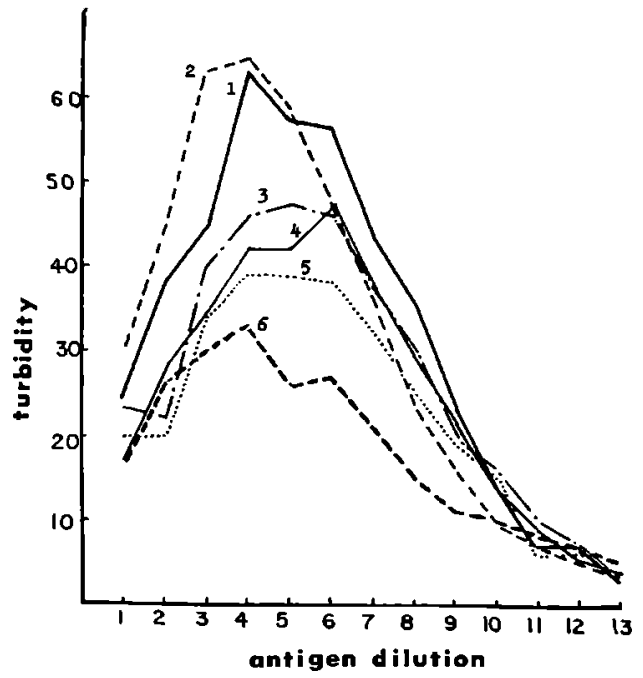

Fig. 2. Results of tests of antiserum of the Leptodactylus chaquensis-Tucuman population with homologous (curve l) and heterologous (curves 2-6) antigens. Forms represented by the latter are: 2, L. chaquensis, Resistencia; 3, L. ocellatus, Bahia Blanca; 4 , L. ocellatus, Mendoza; 5, L. ocellatus, San Luis; 6, L. pentadactylus, Misiones. See legend of Fig. 1 for further explanation.

L. chaquensis from Resistencia was a little lower, to $52.1 \%$.

\section{Discussion}

In spite of the natural variability of results when antisera from different rabbits are tested, the present data justify by their consistency the assumption that by their greater amount of common antigens, Leptodactylus ocellatus and L. chaquensis have a closer blood and genetic relationship than Leptodactylus pentadactylus does with either sibling species.

But the interspecific tests involving $L$. ocel. latus and $L$. chaquensis populations indicate with significant uniformity that the similarity of the serum proteins of these forms does not warrant the conclusion that they are conspecific, as also indicated by other physiological observations and by their overlapping geographic distribution. Further, the few tests as yet carried out with antisera and heterologous antigens from different populations of the same species show a very high degree of serological affinity. Antiserum of Leptodactylus ocellatus from San Luis gave a value of $100 \%$ turbidity with the antigen from the 


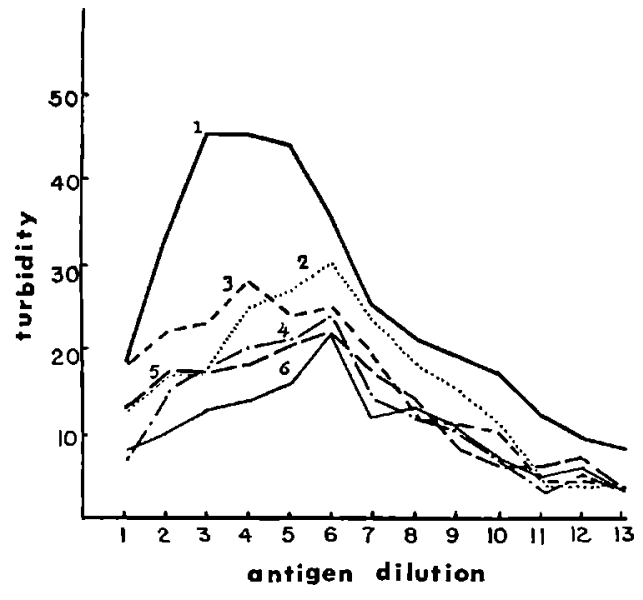

Fig. 3. Results of tests of antiserum of the Leptodactylus pentadactylus-Misiones population with homologous (curve 1) and heterologous (curves 2-6) antigens. Forms represented by the latter are: $2, L$. ocellatus, Mendoza; $3, L$. chaquensis, Resistencia; 4, L. ocellatus, San Luis; 5, L. ocellatus, Bahia Blanca; 6, L. chaquensis, Tucuman. See legend of Fig. 1 for further explanation.

Mendoza population of this species. Likewise, antiserum of Leptodactylus chaquensis from Tucuman showed a $97.3 \%$ reaction with antigen from $L$. chaquensis of Resistencia.

However, Resistencia and Tucuman populations of $L$. chaquensis do not react similarly either with anti-ocellatus or with anti-pentadactylus sera. The Resistencia population is the furthest from the ocellatus group, and its test with ocellatus antiserum was of the same order of magnitude as the test involving $L$. pentadactylus antigens. We have similarly demonstrated geographical variation in the pattern of relative concentration of globulins by means of paper electrophoresis in allsympatric populations of $L$. ocellatus and $L$. chaquensis (Cei and Bertini 1961).

\section{Literature Cited}

Bertini, F., And G. Rathe. 1962. Electrophoretic analysis of hemoglobin of various species of Anurans. Copeia 1962 (1) :181-185.

Boyden, A. 1942. Systematic Serology: A critical appreciation. Physiol. Zool. 15:109-145.

, AND R. J. DE Falco. 1943. Report on the use of the Photronreflectometer in serological comparisons. Ibid. 16:229-241.

- AND D. Gemeroy, 1950. The relative position of the Cetacea among the orders of Mammalia as indicated by precipitin tests. Zoologica 35:145-151.

CEI, J. M. 1948. El ritmo estacional en los fenomenos ciclicos endocrino-sexuales de la rana criolla (Leptodactylus ocellatus (L.)) del Norte Argentino. Acta Zool. Lilloana 6:283331.

1949. Factores genctico-raciales que diferencian la regulacion hormonal del ciclo sexual en Leptodactylus ocellatus de la Argentina. Ibid. $7: 113-134$.

1950. Leptodactylus chaquensis n. sp. y el valor sistematico real de la especie linneana Leptodactylus ocellatus en la Argentina. Ibid. 9:395-423.

- 1962. Mapa preliminar de la distribucion continental de las "sibling species" del grupo ocellatus (genero Leptodactylus). Rev. Soc. Argen. Biol. 38:258-265.

, AND F. Bertini. 1961. Serum proteins in allopatric and sympatric populations of Leptodactylus ocellatus and $L$. chaquensis. Copeia 1961 (3) :336-340.

Cei, J. M., ANd V. ERspamer. 1963. Approach to a biochemical taxonomy through screening of biogenic amines and polypeptides in the skin of South American amphibians. Proc. XVI Intern. Congr. Zool. 1:196.

Cohen, R. 1962. La variación estacional esqueletica como caracter diferencial morfo-fisiologico especifico en Leptodactylus. Rev. Soc. Argen. Biol. 38:366-376.

Gallopin, G. C. 1962. El grupo pachypus del genero Leptodactylus considerado a la luz de las caracteristicas electroforeticas de sus seroproteinas. Physis 23, 65:163-167.

Instituto de Biologia, Universidad Nacional de Guyo, Mendoza, Argentina. 